\title{
Influence of Oestradiol on Protein Expression and Methionine Utilization during Morphogenesis of Paracoccidioides brasiliensis
}

\author{
By KARL V. CLEMONS, ${ }^{*}$ DAVID FELDMAN ${ }^{2}$ AND DAVID A. STEVENS ${ }^{1}$ \\ ${ }^{1}$ Santa Clara Valley Medical Center and Institute for Medical Research, San Jose, \\ California 95128, USA \\ ${ }^{1,2}$ Divisions of Infectious Diseases ${ }^{1}$ and Endocrinology ${ }^{2}$, Department of Medicine, Stanford \\ University School of Medicine, Stanford, California 94305, USA
}

(Received 3 January 1989; accepted I February 1989)

\begin{abstract}
The temporal sequence of cytosolic protein expression during phase transition of Paracoccidioides brasiliensis was examined. Electrophoretic analysis of cytosol proteins by onedimensional SDS-PAGE revealed numerous differences between the mycelial and yeast forms as well as alterations induced by $17 \beta$-oestradiol. Using either protein staining or fluorography of $\left[{ }^{35} \mathrm{~S}\right]$ methionine-labelled proteins 30 phase-specific bands were detected, 12 mycelial-associated bands (range 30 to $140 \mathrm{kDa}$ ) and 18 yeast-associated bands (range 22 to $127 \mathrm{kDa}$ ). In cells undergoing mycelial to yeast transition after a shift from $25^{\circ} \mathrm{C}$ to $37^{\circ} \mathrm{C}$, the protein patterns showed a temporal progression toward the yeast profile with the accumulation of yeast bands prior to observable morphogenesis. Five novel protein bands (range 23 to $50 \mathrm{kDa}$ ) were detected by silver staining during transition. Treatment of temperature-shifted mycelial cultures with $2.6 \times 10^{-7}$ M-oestradiol altered observed profiles; 4 of 12 mycelial-associated bands were maintained whereas the appearance of the 5 novel transition bands and 9 of 18 yeast-associated bands was blocked or delayed. Analysis of $\left[{ }^{35} \mathrm{~S}\right]$ methionine-labelled proteins revealed that oestradiol induced label uptake by mycelial cells, blocked the synthesis of a $92 \mathrm{kDa}$ yeastspecific band $72 \mathrm{~h}$ into transition, and diminished label incorporation $120 \mathrm{~h}$ into transition. In conjunction with these steroid-induced alterations of protein expression, little or no morphological transformation occurred. These results support our hypothesis that, analogous to mammalian steroid receptor action, the functional responses of $P$. brasiliensis to oestradiol are related to regulation of protein expression, presumably mediated via a specific binding proteinligand complex.
\end{abstract}

\section{INTRODUCTION}

Paracoccidioides brasiliensis is one of several medically important fungi exhibiting reversible thermal dimorphism (Kane, 1984; Kobayashi et al., 1985; San-Blas \& San-Blas, 1985). The transition from the saprophytic mycelial-form (M) into the parasitic yeast-form (Y), which is thought to be a requisite step in the establishment of primary infection (Restrepo, 1985), can be induced by a temperature shift from $25^{\circ} \mathrm{C}$ to $37^{\circ} \mathrm{C}$ (San-Blas \& San-Blas, 1985). Several studies have detailed the critical effect of temperature and the temporal appearance of morphological transition forms (Carbonell \& Rodriguez, 1965; Patino et al., 1984; Salazar \& Restrepo, 1984). Less well understood, however, are the metabolic events and regulatory mechanisms involved during the $\mathrm{M}$ to $\mathrm{Y}$ transition. It has been suggested that cAMP may play a regulatory role in the first hours of $\mathrm{M}$ to $\mathrm{Y}$ transition (Paris \& Duran, 1985). Biochemically, alteration of cell wall

* Correspondence should be sent to: Dept of Medicine, Division of Infectious Diseases, Santa Clara Valley Medical Center, 751 South Bascom Avenue, San Jose, CA 95128, USA.

Abbreviations: $\mathrm{E}_{2}, 17 \beta$-oestradiol; $\mathrm{Y}$, yeast; $\mathrm{M}$, mycelial. 
glucans from $\beta(1 \rightarrow 3)$-glycosidic linkages (M-form) to $\alpha(1 \rightarrow 3)$-glycosidic linkages (Y-form) occurs (Kanetsuna et al., 1972; San-Blas \& Vernet, 1977), as well as an apparent reduction in the amount of disulphide linkages. The latter may be associated with the increase of protein sulphide reductase activity in the Y-form (Kanetsuna et al., 1972). Other investigators have demonstrated the $\mathbf{M}$-form of $P$. brasiliensis to be prototrophic for organic sulphur and the $\mathrm{Y}$-form to be auxotrophic, requiring cystine, cysteine or methionine, although the enzymic basis of the auxotrophy is unknown (Paris et al., 1985).

In previous studies we have demonstrated that the vertebrate steroid hormone $17 \beta$-oestradiol $\left(\mathrm{E}_{2}\right)$ inhibits $\mathrm{M}$ to $\mathrm{Y}$ transition of $P$. brasiliensis in a dose-dependent manner (Restrepo et al., 1984). In addition, $P$. brasiliensis possesses a cytosolic protein (EBP) that binds $\mathrm{E}_{2}$ with high affinity and stereospecificity (Loose et al., 1983; Stover et al., 1986). Only those steroid hormones which exhibited affinity for EBP inhibited $M$ to $\mathrm{Y}$ transition; $\mathrm{E}_{2}$ had the highest affinity and the greatest inhibitory activity (Loose et al., 1983; Restrepo et al., 1984). The steroid specificity of this response led to the hypothesis that EBP acts as a receptor which modulates the behaviour of the organism during $M$ to $Y$ transition. To investigate the possibility that $E_{2}$ mediated inhibition of $P$. brasiliensis $\mathrm{M}$ to $\mathrm{Y}$ transition is a result of altered protein synthesis, we examined the patterns of cytosolic proteins present during transition. We demonstrate several $\mathrm{M}$ - and $\mathrm{Y}$-phase specific proteins, as well as $\mathrm{E}_{2}$-induced alterations in the synthesis of specific proteins. In addition, we demonstrate that $M$ to $Y$ transition results in alteration of methionine utilization and that $E_{2}$ exerts an influence on the control of this cellular function.

\section{METHODS}

Growth of organisms. P. brasiliensis (isolate Ber) was utilized throughout the study. Organisms were maintained by serial transfer on agar slopes of modified McVeigh-Morton medium (MVM) (Restrepo \& Jimenez, 1980) and incubated at either $25^{\circ} \mathrm{C}$ for $\mathrm{M}$-form or $37^{\circ} \mathrm{C}$ for $\mathrm{Y}$-form maintenance. Mycelial culture filtrate was collected from MVM broth cultures of $P$. brasiliensis after 2-4 weeks of growth at $25^{\circ} \mathrm{C}$ on a gyratory shaker at 150 r.p.m., filter sterilized and stored at $4{ }^{\circ} \mathrm{C}$ prior to use as a growth supplement. To prepare liquid cultures for phase-transition, $200 \mathrm{ml}$ of fresh MVM supplemented with $100 \mathrm{ml}$ of culture filtrate were inoculated with the M- or Y-form of $P$. brasiliensis as described previously (Stover et al., 1986). Liquid cultures were grown for $8 \mathrm{~d}$ on a gyratory shaker at 150 r.p.m. at $25^{\circ} \mathrm{C}$ (M-phase) or $37^{\circ} \mathrm{C}$ (Y-phase). After the $8 \mathrm{~d}$ growth period, $\mathrm{E}_{2}$, (Steraloids, Wilton, NH, USA) (final concentration $2.6 \times 10^{-7} \mathrm{M}$ in $0.1 \%$ ethanol) or ethanol alone (final concentration $0.1 \%$ ) was added to $\mathrm{M}$ phase cultures. $\mathrm{M}$ to $\mathrm{Y}$ transition was induced in some of these cultures by increasing the incubation temperature from $25^{\circ} \mathrm{C}$ to $37^{\circ} \mathrm{C}$, shaking at 150 r.p.m. over a period of 24 to $120 \mathrm{~h}$ after treatment. M-phase controls remained at $25^{\circ} \mathrm{C}$ and 150 r.p.m. shaking for an additional $24 \mathrm{~h}$ after the addition of $\mathrm{E}_{2}$ or ethanol prior to sample preparation. Y-phase controls remained at $37^{\circ} \mathrm{C}$ throughout the period of incubation.

Sample preparation. At various times after the initiation of phase-transition, cultures were collected for analysis. In certain experiments the organisms from the $300 \mathrm{ml}$ cultures were concentrated into $10 \mathrm{ml}$ by centrifugation $\left(1500 \mathrm{~g}, 15 \mathrm{~min}, 25^{\circ} \mathrm{C}\right)$. These cultures were pulsed for the final $2 \mathrm{~h}$ of their incubation period (i.e. pulsed from 22 to $24 \mathrm{~h}, 70$ to $72 \mathrm{~h}$ or 118 to $120 \mathrm{~h})$ at the appropriate temperature with $3.7 \mathrm{MBq}\left[{ }^{35} \mathrm{~S}\right]$ methionine $(1.5$ $18.5 \mathrm{GBq} \mathrm{mmol}^{-1}$; Amersham) with or without the addition of $10 \mu \mathrm{M}$ unlabelled methionine. After the $2 \mathrm{~h}$ pulse, the cultures were diluted to $50 \mathrm{ml}$ with sterile distilled water, harvested by centrifugation $\left(1500 \mathrm{~g}, 15 \mathrm{~min}, 4^{\circ} \mathrm{C}\right)$, washed once in ice-cold homogenization buffer $[62.5 \mathrm{~mm}$-Tris $/ \mathrm{HCl}, 4 \mathrm{~mm}-\mathrm{EDTA}, 4 \%(\mathrm{v} / \mathrm{v})$ 2-mercaptoethanol, $10 \%(\mathrm{v} / \mathrm{v})$ glycerol, $\mathrm{pH} 6.8 \mathrm{]}$ and resuspended in homogenization buffer $(50: 50, \mathrm{v} / \mathrm{v})$. Cultures not radiolabelled were harvested directly by centrifugation and washed as described.

Cells were disrupted by vigorous agitation of the cell suspension with glass beads $(0.45 \mathrm{~mm})$ on a vortex mixer and cytosol collected from the broken cell suspensions as described previously (Stover et al., 1986). Tubes were kept cold throughout the procedure by immersion in ice. Each cytosol sample was assayed for protein by the technique of Bradford (1976) and, when appropriate, assessed for radioactivity. All cytosols were stored at $-70{ }^{\circ} \mathrm{C}$ until required for electrophoresis.

SDS-PAGE techniques. Samples were prepared for electrophoresis by the addition of $20 \%(\mathrm{w} / \mathrm{v})$ SDS in homogenization buffer to make a final concentration of $2 \%(\mathrm{w} / \mathrm{v})$ SDS and boiled for $5 \mathrm{~min}$. Bromophenol blue $(0.001 \%)$ served as the tracking dye. Samples, whose content was standardized by equivalence of protein concentration or c.p.m. of radioactivity, were loaded and electrophoresed through a SDS-PAGE gel, $9 \%$ running gel, 4.5\% stacking gel (37.5:1, acrylamide/bis-acrylamide) essentially as described by Laemmli (1970).

Proteins were visualized on some gels by silver staining. Gels run to assess de novo protein synthesis were first stained with Coomassie Brilliant Blue R250 and further processed for fluorography as described by Bonner \& Laskey (1974). Exposure to X-ray film (XOmat AR, Kodak) was done at $-70^{\circ} \mathrm{C}$ for a period of $7-21 \mathrm{~d}$. Results were assessed visually for qualitative changes in banding patterns. 
RESULTS

\section{Comparison of cytosolic proteins from mycelial and yeast cells}

Although the M- and Y-forms of $P$. brasiliensis are morphologically distinct, differences in cytosolic protein patterns have not been described previously. To assess whether differences in protein pattern existed between $\mathrm{M}$ - and $\mathrm{Y}$-form, $P$. brasiliensis was grown in liquid culture at $25^{\circ} \mathrm{C}$ (M-form) or $37^{\circ} \mathrm{C}$ (Y-form), and the cytosols compared using one-dimensional SDSpolyacrylamide gels. Analysis of protein banding patterns was done qualitatively by visual examination. Only those differences observed in each of five silver stain experiments or two of three fluorography experiments were considered reproducible and are described. It should be noted that qualitative and quantitative band differences may be observed in the Figures which were not reproducible. These changes are not described.

Protein patterns visualized by silver staining indicated that each morphological form (M or $\mathrm{Y}$ ) of $P$. brasiliensis was distinct (Fig. 1). Based on the conditions stated above, a total of 30 bands met these criteria and were considered to be reproducible. The M-form contained 12 bands not discernible in the Y-form, ranging from approximately $30 \mathrm{kDa}$ to $140 \mathrm{kDa}$. The Y-form was observed to have 18 bands not present in the $\mathrm{M}-\mathrm{form}$, ranging from approximately $22 \mathrm{kDa}$ to $127 \mathrm{kDa}$. Representative protein patterns are shown in Fig. 1, with only form-specific differences that are discerned easily in the reproduction indicated. In addition to the differences indicated in Fig. 1, M-form specific bands of 140 and $30.5 \mathrm{kDa}$ and $\mathrm{Y}$-form specific bands at $119,108,102,93,82$, and $62 \mathrm{kDa}$ were observed.

Differences in patterns of de novo synthesized cytoplasmic proteins were assessed by $\left[{ }^{35} \mathrm{~S}\right]-$ methionine incorporation. Preliminary experiments indicated that although the Y-form incorporated the label into many cytosolic proteins, a minimal amount of label was incorporated by $\mathrm{M}$-form into $\mathrm{M}$-form proteins. The addition of $10 \mu \mathrm{M}$ unlabelled methionine to $\mathrm{M}$ cultures during the $2 \mathrm{~h}$ labelling period resulted in substantial $\left[{ }^{35} \mathrm{~S}\right]$ methionine incorporation into cytosolic proteins (Fig. 2, lane 1). The addition of unlabelled methionine to Y-form cultures did not alter their pattern of $\left[{ }^{35} \mathrm{~S}\right]$ methionine incorporation (data not shown). The banding patterns of $\left[{ }^{35}\right.$ S $]$ methionine labelled proteins were fairly similar to those presented in Fig. $1 ; 7$ of $12 \mathrm{M}$ specific and 13 of $18 \mathrm{Y}$-specific bands were discernible. One $\mathrm{M}$-form band at $30.5 \mathrm{kDa}$ and one $\mathrm{Y}$-form band at $108 \mathrm{kDa}$ are not indicated in Fig. 2. Several $\mathrm{M}$ - and $\mathrm{Y}$-specific bands detectable by silver staining were not detected by fluorography. However, the protein patterns of $\mathrm{M}$ - and $\mathrm{Y}$ forms were distinct when compared by either method (Figs 1 and 2).

\section{Comparison of cytosolic proteins of hormone-treated and control cells}

The possible influence of $E_{2}$ treatment on protein patterns was assessed by one-dimensional SDS-PAGE of cytosolic proteins from hormone-treated and control cells at various times during the course of $\mathrm{M}$ - to $\mathrm{Y}$-form transition. $P$. brasiliensis $\mathrm{M}$ - and $\mathrm{Y}$-form transition was observed microscopically in liquid shaker cultures within $120 \mathrm{~h}$ after a temperature shift from $25^{\circ} \mathrm{C}$ to $37^{\circ} \mathrm{C}$, but was $85 \%$ inhibited by concentration of $2.6 \times 10^{-7} \mathrm{M}-\mathrm{E}_{2}$.

Although protein patterns of $\mathrm{M}$ and $\mathrm{Y}$ controls were very consistent, temporal protein patterns during transition proved to be variable in the disappearance or appearance of formspecific bands. Because these results suggested asynchrony of the cells during the extended events of morphological transition, only those changes observed in at least three replicate experiments were considered reproducible.

There were no reproducible differences in total protein stained patterns between ethanoltreated and $E_{2}$-treated $M$ cultures maintained for $24 \mathrm{~h}$ at $25^{\circ} \mathrm{C}$ (Figs 3 and 4, lanes 1). However, after the temperature shift from $25^{\circ} \mathrm{C}$ to $37^{\circ} \mathrm{C}$ numerous changes occurred during the $120 \mathrm{~h}$ assay period of $\mathrm{M}$ - to $\mathrm{Y}$-form transition. Ethanol-treated control cultures gradually acquired $\mathrm{Y}$ bands with the concurrent disappearance of $\mathrm{M}$ bands, their protein patterns becoming most yeast-like by $120 \mathrm{~h}$ of transition (Fig. 3, lane 4). These results correlated with the microscopic changes in morphology (data not shown). Morphological $M$ to $Y$ transition was blocked by $E_{2}$, and the temporal sequence of protein patterns was altered. After the temperature shift, the pattern of the M-form was maintained through $72 \mathrm{~h}$ and comparatively fewer $\mathrm{Y}$-form bands had appeared after $120 \mathrm{~h}$ of transition in $\mathrm{E}_{2}$-treated cells (Fig. 4, lanes 2-4). M-form bands of 123, 99, 


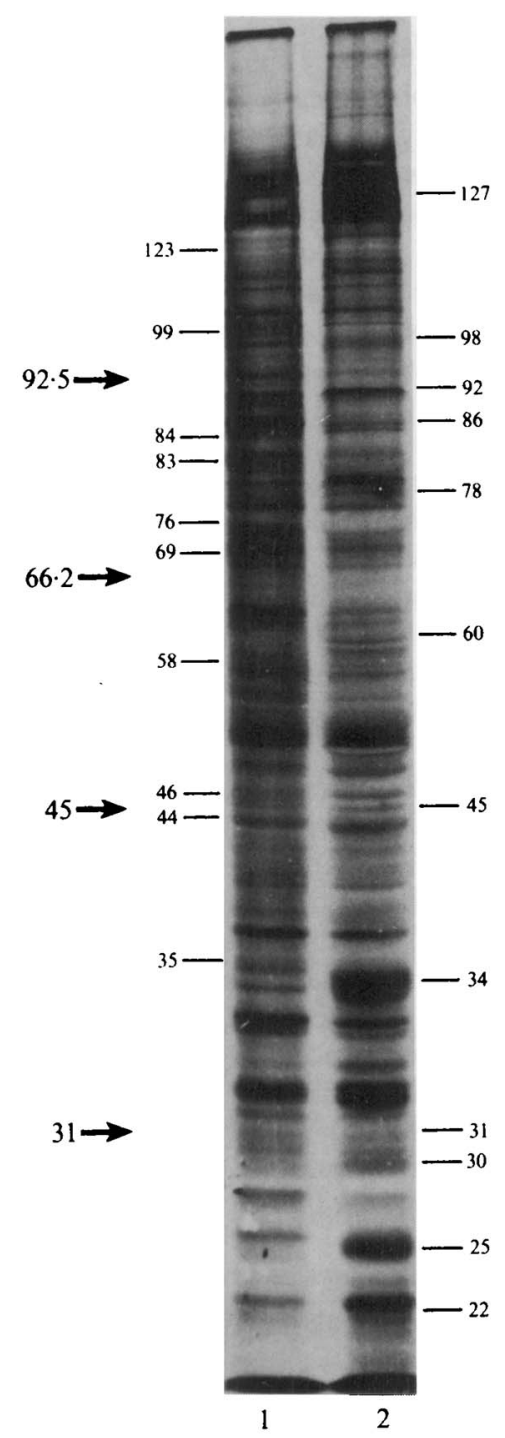

Fig. 1

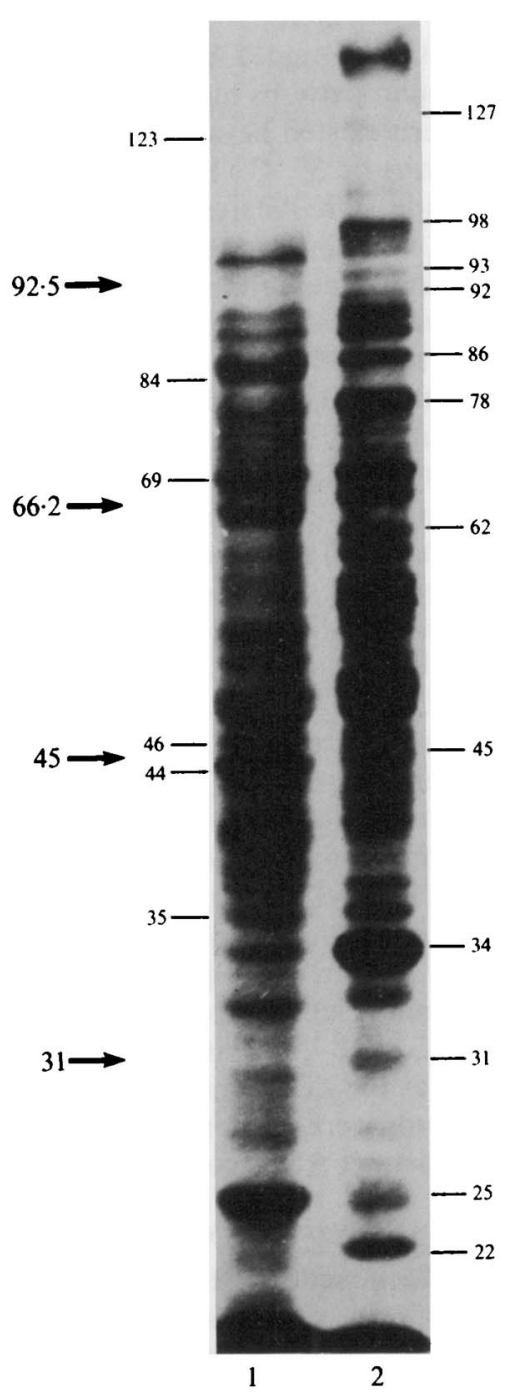

Fig. 2

Fig. 1. Comparison of proteins from the cytosol fractions of $\mathbf{M}$ and $\mathrm{Y}$ form of $P$. brasiliensis. Proteins (10 $\mu$ g per lane) were resolved by one-dimensional electrophoresis through $9 \%$ SDS-PAGE gels and silver stained. Lane 1 shows mycelial proteins with the estimated molecular mass in $\mathrm{kDa}$ of $\mathrm{M}$-specific proteins on the left; lane 2 shows yeast proteins with the estimated molecular mass in $\mathrm{kDa}$ of $\mathrm{Y}$-specific proteins at the right. Only those phase-specific proteins which are readily discernible in the photograph are indicated. Respective positions of molecular mass standards in $\mathrm{kDa}$ (phosphorylase $b, 92 \cdot 5$; bovine serum albumin, 66.2; ovalbumin, 45; carbonic anhydrase, 31 ) are noted on the far left.

Fig. 2. Comparison of $\left.{ }^{35} S\right]$ methionine labelled proteins of $\mathbf{M}$ and $\mathbf{Y}$ cells. $\mathbf{M}$ phase proteins were labelled in the presence of excess radioinert methionine as described in Methods. Cells were labelled for $2 \mathrm{~h}$ prior to disruption and fractionation. Electrophoretic conditions were the same as described in Fig. 1. Gel lanes were loaded with the same number of c.p.m. (approximately 40000) and processed for fluorography. As in Fig. 1, only readily discerned phase-specific bands are indicated. Lane 1 shows mycelial proteins, with specific bands indicated at the near left; lane 2 shows yeast proteins with specific bands noted on the right. Molecular mass standards in kDa are indicated at the far left. 


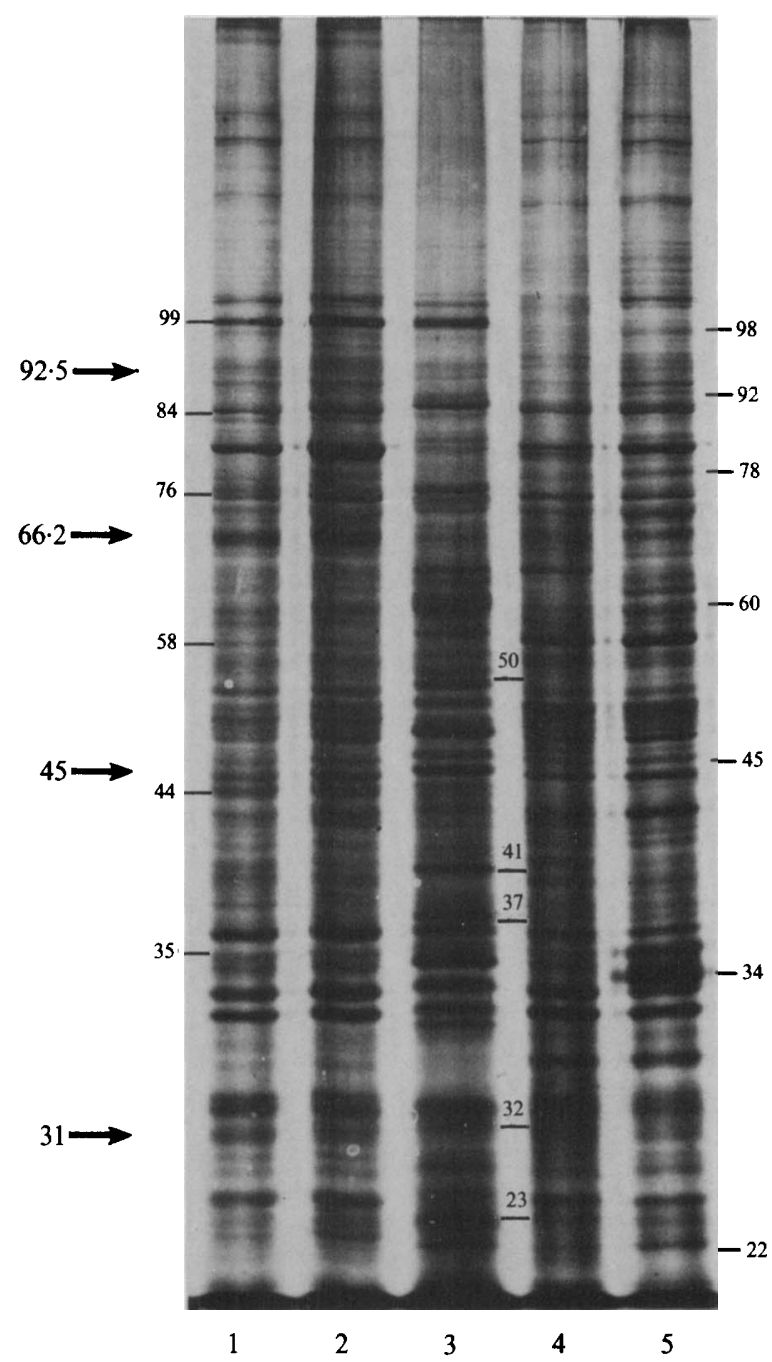

Fig. 3. Comparison of proteins from the cytosol fractions of untreated $P$. brasiliensis undergoing $\mathrm{M}$ to $\mathrm{Y}$ transition. Electrophoretic conditions were as described in Fig. 1. Proteins were visualized by silver staining. Lane $1, \mathrm{M}$-form cells incubated solely at $25^{\circ} \mathrm{C}$; lanes 2,3 and 4 cells preincubated at $25^{\circ} \mathrm{C}$ and switched to $37^{\circ} \mathrm{C}$ for 24,72 and $120 \mathrm{~h}$, respectively. Lane $5, \mathrm{Y}$ cells incubated only at $37^{\circ} \mathrm{C}$. Novel transition bands are indicated between lanes 3 and 4 , with the estimated molecular mass in $\mathrm{kDa}$. For reference, several $\mathrm{M}$ and $\mathrm{Y}$-specific bands are indicated with the estimated molecular mass in $\mathrm{kDa}$ at the near left and right, respectively. Molecular masses in $\mathrm{kDa}$ of standards are indicated on the far left.

83 and $46 \mathrm{kDa}$ were maintained, whereas $\mathrm{Y}$-form bands of 102, 98, 93, 92, 78, 34, 31, 30 and $22 \mathrm{kDa}$ were blocked or delayed in appearance as compared to controls. Novel transition bands of $50,41,37,32$ and $23 \mathrm{kDa}$ were observed in the ethanol-treated controls by $24 \mathrm{~h}$ and/or $72 \mathrm{~h}$, but had disappeared by $120 \mathrm{~h}$ of transition (Fig. 3, lanes 2-4). These bands were absent or delayed in appearance to $120 \mathrm{~h}$ of transition in $\mathrm{E}_{2}$-treated cells (Fig. 4, lanes 2-4). In addition, fewer total bands were present in $E_{2}$-treated cells after $120 \mathrm{~h}$ of transition as compared to the respective control (Figs 3 and 4, lane 4). 


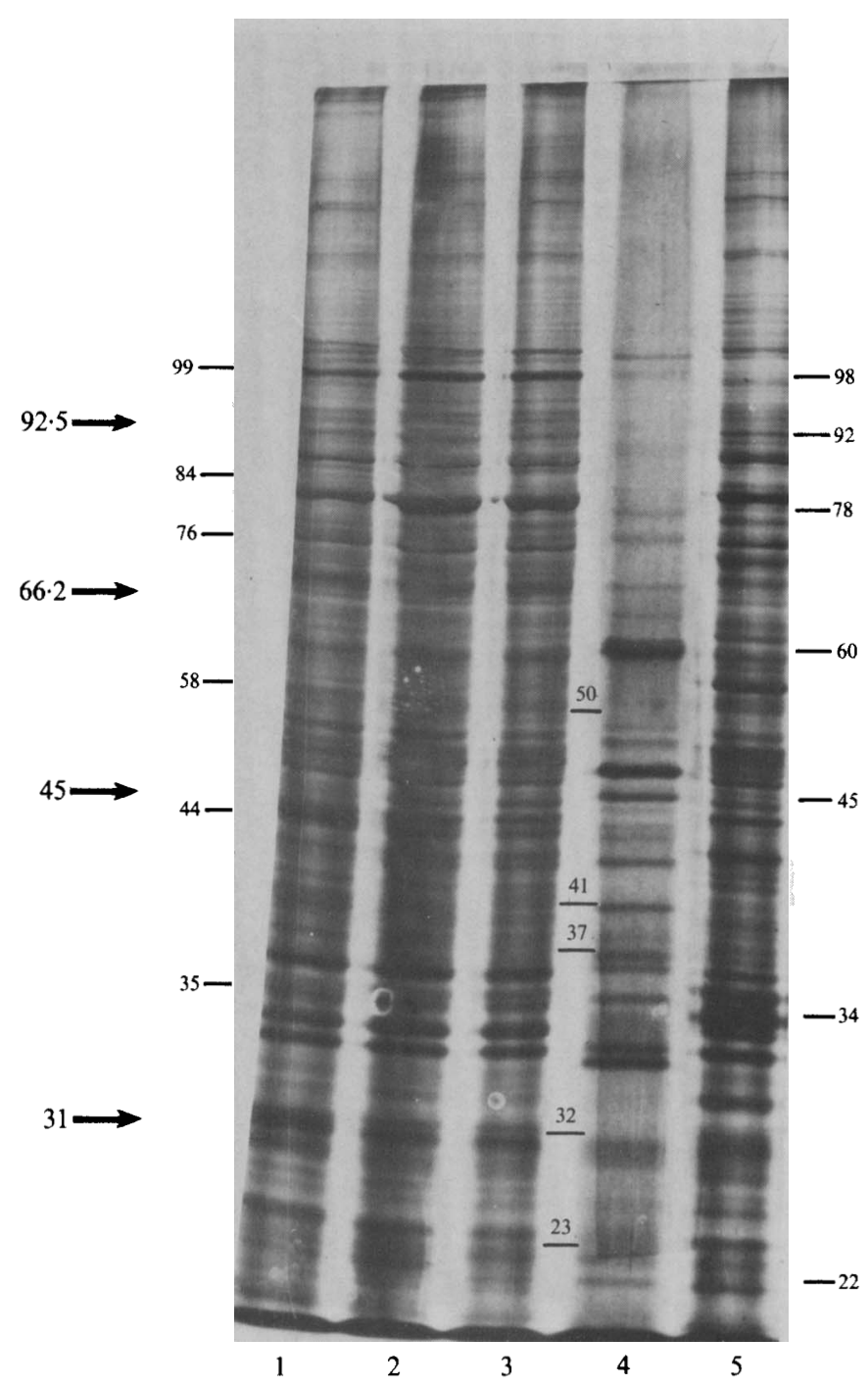

Fig. 4. Comparison of proteins frum the cytosol fractions of $\mathrm{E}_{2}$-treated $P$. brasiliensis undergoing $\mathrm{M}$ to $\mathrm{Y}$ transition with $\mathrm{M}$ and $\mathrm{Y}$ controls. Proteins were resolved through $9 \%$ SDS-PAGE and silver stained. Lane 1, M-cells incubated solely at $25^{\circ} \mathrm{C}$, treated with $\mathrm{E}_{2}$ for $24 \mathrm{~h}$; lanes 2, 3, and 4, M-cells after 24, 72, and $120 \mathrm{~h}$ of $\mathrm{E}_{2}$ treatment at $37^{\circ} \mathrm{C}$, respectively. Lane 5, Y-cells incubated at $37^{\circ} \mathrm{C}$ only. Lanes $1-4$ represent $M$ cultures treated with $E_{2}\left(2.6 \times 10^{-7} \mathrm{M}\right)$, and lane 5 represents the $Y$ control. Note the maintenance of the M-form profile at 24 and $72 \mathrm{~h}$ (lanes 2 and 3 ) and the decreased total number of bands by $120 \mathrm{~h}$ (lane 4), which demonstrates little similarity to the Y-form profile (lane 5). For reference, the molecular mass in $\mathrm{kDa}$ of the transition bands (between lanes 3 and 4) as well as selected $\mathrm{M}$-specific (near left) and $\mathrm{Y}$-specific (near right) bands are indicated. Molecular masses in $\mathrm{kDa}$ of standards are indicated on the far left.

\section{Comparison of $\left[{ }^{35}\right.$ S $]$ methionine-labelled proteins}

To assess the temporal sequence of proteins synthesized de novo by control and hormonetreated cells during M- to Y-form transition, cultures were pulsed with [ ${ }^{35}$ S]methionine for $2 \mathrm{~h}$ n.ine to dicruntion and cutosol nroteins visualized by fluorography of gels. Additional 


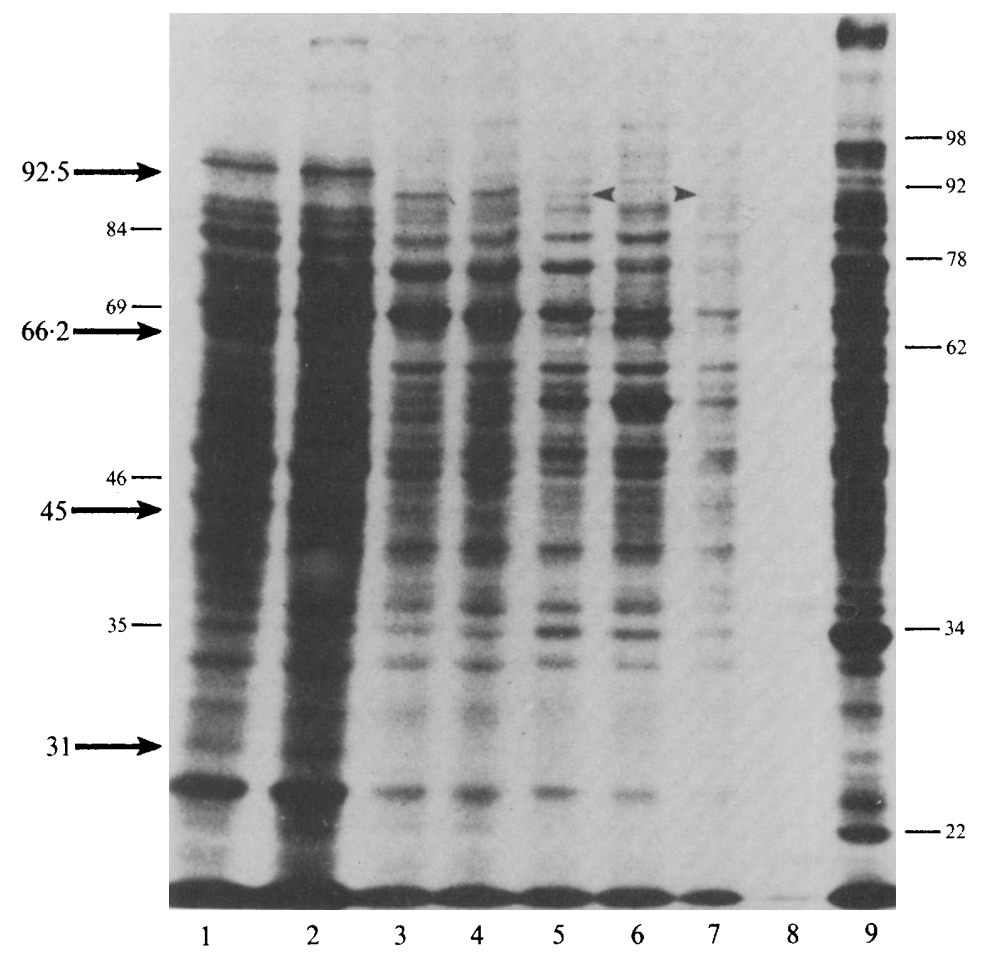

Fig. 5. Comparison of $\left[{ }^{35} S\right]$ methionine-labelled protein fractions of hormone-treated and untreated $P$. brasiliensis undergoing $\mathrm{M}$ to $\mathrm{Y}$ transition. Labelling was done in the presence of radioinert methionine for lanes 1 and 2, and in the absence of radioinert methionine for lanes 3-9. Gels were run and analysed as in Fig. 2. Lane assignments are as follows: 1, $\mathrm{M}$ control; 2, $\mathrm{M} \mathrm{E}_{2}$-treated; 3, 5, and 7, $\mathrm{M}$ controls grown at $37^{\circ} \mathrm{C}$ for $24 \mathrm{~h}, 72 \mathrm{~h}$ and $120 \mathrm{~h}$, respectively. Lanes 4,6 , and 8 are $\mathrm{M}$ treated with $\mathrm{E}_{2}$ $\left(2.6 \times 10^{-7} \mathrm{M}\right)$ grown at $37^{\circ} \mathrm{C}$ for $24 \mathrm{~h}, 72 \mathrm{~h}$ and $120 \mathrm{~h}$, respectively. Lane 9 is the yeast control. Note the absence of the $92 \mathrm{kDa}$ band in lane 6 and few labelled bands in lane 8 . The positions of selected $\mathrm{M}$ - and $\mathrm{Y}$-specific bands with estimated molecular mass in $\mathrm{kDa}$ are indicated for reference at the near left and right, respectively. Molecular masses in $\mathrm{kDa}$ of standards are indicated at far left.

not by $\mathrm{Y}$-form or $\mathrm{M}$ to $\mathrm{Y}$ transitional cultures. Profile differences were not apparent between control and $\mathrm{E}_{2}$-treated $25^{\circ} \mathrm{C} \mathrm{M}$ cells when labelled in the presence of excess radioinert methionine (Fig. 5, lanes 1 and 2). However, control and $\mathrm{E}_{2}$-treated $25^{\circ} \mathrm{C} \mathrm{M}$ cells labelled in the absence of excess methionine displayed dramatic pattern differences (Fig. 6, lanes 1 and 2). Whereas few if any labelled proteins were apparent from $25^{\circ} \mathrm{C} \mathrm{M}$ controls (Fig. 6, lane 1), $24 \mathrm{~h}$ of hormone treatment reproducibly enhanced $\left[{ }^{35} \mathrm{~S}\right]$ methionine uptake and incorporation into several cytosolic proteins by nontransforming $25^{\circ} \mathrm{C} \mathrm{M}$ cells (Fig. 6, lane 2).

Acquisition of $\mathrm{Y}$-specific and disappearance of $\mathrm{M}$-specific proteins were observed after $24 \mathrm{~h}$ of $\mathrm{M}$ to $\mathrm{Y}$ transition in both control and hormone-treated temperature-shifted cells (Fig. 5, lanes 3 and 4). By $72 \mathrm{~h}$ and $120 \mathrm{~h}$ of $\mathrm{M}$ to $\mathrm{Y}$ transition, $\mathrm{E}_{2}$ treatment had resulted in detectable differences. Most notable was the reduction and probable absence of a $Y$-specific band (approximately $92 \mathrm{kDa}$ ) present in control $\mathrm{M}$ to $\mathrm{Y}$ transition cultures which was not observable in the profile of $E_{2}$-treated cells (Figs 5 and 6, lanes 5 and 6). A second overall difference relating to the total number of labelled bands was observed in the comparative profiles after $120 \mathrm{~h}$ of $\mathrm{M}$ to $\mathrm{Y}$ transition (Fig. 5, lanes 7 and 8 ). As is evident, $\left[{ }^{35} \mathrm{~S}\right]$ methionine incorporation and presumably protein synthesis was reduced, with many fewer bands observable in $E_{2}$-treated cells after $120 \mathrm{~h}$ of $\mathrm{M}$ to $\mathrm{Y}$ transition, whereas the control $\mathrm{M}$ to $\mathrm{Y}$ transition cultures exhibited 


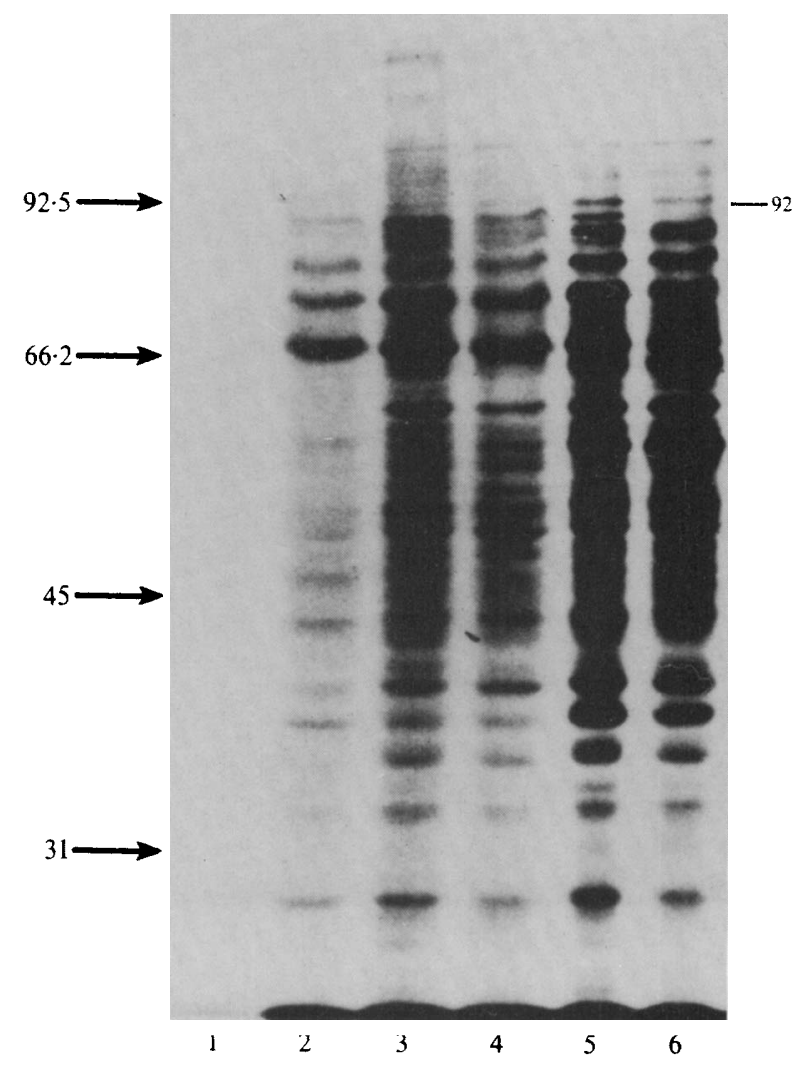

Fig. 6. Comparison of $\left[{ }^{35} \mathrm{~S}\right]$ methionine-labelled proteins in cytosol fractions of $\mathrm{E}_{2}$-treated and untreated $P$. brasiliensis undergoing $\mathrm{M}$ to $\mathrm{Y}$ transition. Labelling was done in the absence of radioinert methionine. Gels were prepared and analysed as in Fig. 2. Lane assignments 1-6 are the same as in Fig. 5. Note the effect of $\mathrm{E}_{2}$ on label incorporation of $\mathrm{M}$-form (lane 2) as compared to untreated control (lane 1). Absence of the $92 \mathrm{kDa} \mathrm{Y}$-specific band in lane 6 is indicated as in Fig. 5. The fluorogram was intentionally over-exposed to enhance the bands in lane 2 . Molecular masses in $\mathrm{kDa}$ of standards are indicated on the left.

incorporation and a $Y$ protein synthesis profile (Fig. 5, lanes 7-9). In separate experiments, reduction in the number of bands present in $\mathrm{E}_{2}$-treated cells was noted by total protein staining (Fig. 4, lane 4).

These results indicated that the switch to utilization and incorporation of exogenous methionine occurs within $24 \mathrm{~h}$ of temperature increase to $37^{\circ} \mathrm{C}$ (Fig. 6, lanes 1 and 3) and that the synthesis of $\mathrm{Y}$ proteins began 24 to $72 \mathrm{~h}$ before observable morphological changes occurred.

\section{DISCUSSION}

In the present investigation, the temporal sequence of protein expression by $\mathbf{E}_{2}$-treated and non-treated cells of $P$. brasiliensis was studied during $\mathrm{M}$ to $\mathrm{Y}$ transition. The results presented here are in accord with and extend previous studies on temperature-induced form-transition by $P$. brasiliensis. Further, these results indicate that not only can temperature induce differential protein expression in this organism, but that the mammalian steroid hormone, $E_{2}$, exerts demonstrable effects on protein expression. Because the morphological form of $P$. brasiliensis appears to be influenced primarily by the temperature of incubation (Patino et al., 1984; SanBlas \& San-Blas, 1985), it would be attractive to postulate form-specific repression or 
derepression of the synthesis of some cellular proteins. Results of the present study are in accord with this hypothesis in that some proteins were observed to be associated with only the M-or Yform and that during transition the $M$ pattern progressively changed to the $Y$ pattern. In addition, the appearance of novel transition bands suggest that they are involved in the morphological transition itself. The inconsistency of appearance of these bands, and the lack of detection by ${ }^{[35}$ S]methionine labelling, may be due in part to the relative asynchrony of these multinuclear fungal cells during the extended event of transition in combination with the short 'labelling window' utilized. Similarly novel transition proteins have been reported to occur during form-transition of Candida albicans and were designated as heat-shock proteins (Dabrowa \& Howard, 1984). Whether or not the transition proteins observed in this study of $P$. brasiliensis are true heat-shock-type proteins as expressed by other prokaryotes and eukaryotes (Neidhardt et al., 1984) remains to be determined.

Lambowitz et al. (1983), in studies with Histoplasma capsulatum, have proposed that dimorphism may be a byproduct of the heat shock response, occurring over a period of days with marked changes to oxidative phosphorylation and a switch to cysteine auxotrophy after shifting the temperature from $25^{\circ} \mathrm{C}$ to $37^{\circ} \mathrm{C}$ (Maresca et al., 1981; Medoff et al., 1987a). Likewise, a switch to Y-form auxotrophy for sulphur-containing amino acids (Paris et al., 1985) and the uncoupling of oxidative phosphorylation as well as a cysteine requirement during transition (Medoff et al., 1987 b) has been described for P. brasiliensis. In accord, our results clearly demonstrate increased translocation and incorporation of $\left[{ }^{35} \mathrm{~S}\right] \mathrm{methionine}$ by $\mathrm{Y}$-form cells, whereas $\mathbf{M}$-form cells incorporated little if any label. This change indicates increased utilization and possible growth requirement or auxotrophy for methionine in the Y-form. However, incorporation of $\left.{ }^{[35} \mathrm{S}\right]$ methionine by the $\mathrm{M}$-form could be enhanced by increasing the extracellular concentration of methionine and appears to indicate a down-regulated, but fully functional, methionine translocation system. It is of interest that $\left[{ }^{35} \mathrm{~S}\right]$ methionine was incorporated well by cells $24 \mathrm{~h}$ after the initiation of transition. This change might be a result of diminished cellular capacity to synthesize methionine with subsequent up-regulation of a translocation system occurring to provide the cells with required methionine. These results are similar to those with $H$. capsulatum (Maresca et al., 1981) and demonstrate that a switch in methionine metabolism by $P$. brasiliensis occurs several days before visible morphogenesis.

In conjunction with these temperature-related changes, the potential influence of $E_{2}$ on cellular protein patterns during $M$ to $Y$ transition was examined. Classically, steroid hormone action in mammalian systems is mediated via a receptor-ligand-DNA complex which regulates the expression of specific proteins (Yamamoto, 1985). In some fungi, mating pheromones regulate sexual reproduction and induce alterations in protein expression. Tremerogen $A-10$ and $a-13$ induce expression of cell-surface proteins in the gametes of Tremella mesenterica (Miyakawa et al., 1984). Antheridiol, secreted by female cells of Achlya ambisexualis, induces protein expression in male cells (Brunt \& Silver, 1986 $a, b, 1987$ ) which is regulated via a specific antheridiol receptor (Riehl et al., 1984; Riehl \& Toft, 1984). Although sexual mating is not known to occur in $P$. brasiliensis, steroid hormones may influence the organism. The possibility exists that $E_{2}$ in combination with the increase in temperature may in some manner directly affect the functions of cellular components, such as microsomal enzymes, necessary for phasetransition. However, we have demonstrated the presence of EBP, a cytosolic protein $(\approx 60 \mathrm{kDa})$ which specifically binds $E_{2}$. Because of the specificity of the response we postulated that EBP, acting as a receptor for $\mathrm{E}_{2}$, mediates $\mathrm{E}_{2}$ inhibition of $\mathrm{M}$ - to $\mathrm{Y}$-phase transition (Loose et al., 1983; Restrepo et al., 1984; Stover et al., 1986). In accord with this hypothesis, the present study indicates that $\mathrm{E}_{2}$ alters protein expression in $P$. brasiliensis undergoing transition.

Although some differences in protein patterns were detectable by silver staining, alterations in de novo protein synthesis were the most dramatic. Unlike Tremella (Miyakawa et al., 1984) and Achlya (Brunt \& Silver, 1986a,b), where the specific pheromones primarily induce new proteins, $E_{2}$ (which blocks a morphological event) blocked or delayed the synthesis of numerous proteins. Of these, most notable were the absence of a $92 \mathrm{kDa} \mathrm{Y}$-specific band and the almost total ablation of de novo protein synthesis $120 \mathrm{~h}$ into the transition process. Thus, these results indicate that the inhibition of $M$ to $Y$ transition by $E_{2}$ is linked to repression of protein 
synthesis. Because previous studies have shown no effects on $\mathrm{Y}$ to $\mathbf{M}$ transition or $\mathrm{Y}$-form growth (Loose et al., 1983; Restrepo et al., 1984) and because $\mathrm{E}_{2}$-treated cells continued to incorporate methionine through $72 \mathrm{~h}$ of transition, we do not feel that the ablation of protein synthesis was caused by an immediate or direct toxicity of $E_{2}$. The mechanism and duration of these responses to $E_{2}$ remain to be determined.

An unexpected finding in this study was that $\mathrm{E}_{2}$ exerted an effect on the M-form of $P$. brasiliensis not undergoing phase transition. While $\mathrm{M}$-form organisms did not readily incorporate $\left[{ }^{35} \mathrm{~S}\right]$ methionine into cytosolic proteins, $\mathrm{E}_{2}$ treatment of $\mathrm{M}$-form resulted in label incorporation. Although paradoxical, the switch by $\mathrm{M}$-form cells to an ability to translocate and incorporate methionine, a property associated with the Y-form, is the first reported metabolic response exhibited by $M$-form $P$. brasiliensis to the presence of $E_{2}$. While the regulatory basis of this change is not known, it is interesting to note the similarity between this response induced by $\mathrm{E}_{2}$ and the normal switch in nontreated cells after an increase in temperature. Thus, it is possible that our results reflect induction by $\mathrm{E}_{2}$ of a stress-type response by $\mathrm{M}$-form $P$. brasiliensis, which is pleiotropic in effect.

The distinct protein patterns of $\mathrm{M}$ - and $\mathrm{Y}$-form cells are suggestive of temperature-regulated protein expression in $P$. brasiliensis. Furthermore, several days prior to visible morphological changes during the $\mathrm{M}$ - to $\mathrm{Y}$-phase transition, differential protein expression occurs in a temporal fashion which can be modulated by $\mathrm{E}_{2}$-treatment.

This study was supported by Public Health Service grant AI-20409 from the National Institutes of Health and by National Science Foundation grant INT-8601654.

\section{REFERENCES}

BonNer, W. M. \& LASKey, R. A. (1974). A film detection method for tritium-labelled proteins and nucleic acids in polyacrylamide gels. European Journal of Biochemistry 46, 83-88.

BRADFORD, M. M. (1976). A rapid and sensitive method for the quantitation of microgram quantities of protein utilizing the principle of protein-dye binding. Annals of Biochemistry 72, 248-254.

BRUNT, S. A. \& SILVER, J. C. (1986a). Steroid hormoneinduced changes in secreted proteins in the filamentous fungus Achlya. Experimental Cell Research 163 , 22-34.

Brunt, S. A. \& Silver, J. C. (1986b). Cellular localization of steroid hormone-regulated proteins during sexual development in Achlya. Experimental Cell Research 165, 306-319.

Brunt, S. A. \& Silver, J. C. (1987). Steroid hormoneregulated basic proteins in Achlya ambisexualis. Experimental Mycology 11, 65-69.

Carbonell, L. \& Rodriguez, J. (1965). Transformation of mycelial and yeast forms of Paracoccidioides brasiliensis in cultures and in experimental inoculations. Journal of Bacteriology 90, 504-510.

DaBRowa, N. \& HowaRD, D. H. (1984). Heat shock and heat stroke proteins observed during germination of the blastoconidia of Candida albicans. Infection and Immunity 44, 537-539.

KANE, J. (1984). Conversion of Blastomyces dermatitidis to the yeast form at $37^{\circ} \mathrm{C}$ and $26^{\circ} \mathrm{C}$. Journal of Clinical Microbiology 20, 594-596.

Kanetsuna, F., Carbonell, L. M., Azuma, I. \& Yamamura, Y. (1972). Biochemical studies on the thermal dimorphism of Paracoccidioides brasiliensis. Journal of Bacteriology 110, 208-218.

Kobayashi, G. S., Medoff, G., Maresca, B., Sacco, M. \& Kumar, B. V. (1985). Studies on phase transitions in the dimorphic pathogen Histoplasma capsulatum. In Fungal Dimorphism with Emphasis on Fungi Pathogenic for Humans, pp. 69-91. Edited by P. J. Szaniszlo \& J. L. Harris. New York: Plenum Press.

LAEMMLI, U. K. (1970). Cleavage of structural proteins during the assembly of the head of bacteriophage T4. Nature, London 227, 680-685.

Lambowitz, A. M., Kobayashi, G. S., Painter, A. \& MEDOFF, G. (1983). Possible relationship of morphogenesis in pathogenic fungus, Histoplasma capsulatum, to heat shock response. Nature, London $\mathbf{3 0 3}$, 806-808.

Loose, D. S., Stover, E. P., Restrepo, A., Stevens, D. A. \& Feldman, D. (1983). Estradiol binds to a receptor-like cytosol binding protein and initiates a biological response in Paracoccidioides brasiliensis. Proceedings of the National Academy of Sciences of the United States of America 80, 7659-7663.

Maresca, B., Lambowitz, A. M., Kumar, V. B., Grant, G. A., Kobayashi, G. S. \& Medoff, G. (1981). Role of cysteine in regulating morphogenesis and mitochondrial activity in the dimorphic fungus Histoplasma capsulatum. Proceedings of the National Academy of Sciences of the United States of America 78, 4596-4600.

Medoff, G., Kobayashi, G. S., Painter, A. \& Travis, S. (1987a). Morphogenesis and pathogenicity of Histoplasma capsulatum. Infection and Immunity 55, 1355-1358.

Medoff, G., Painter, A. \& Kobayashl, G. S. (1987b). Mycelial-to-yeast-phase transitions of the dimorphic fungi Blastomyces dermatitidis and Paracoccidioides brasiliensis. Journal of Bacteriology 169, 40554060.

Miyakawa, T., Kadota, T., Okubo, Y., Hatano, T., TsuchiYA, E. \& FukUi, S. (1984). Mating pheromone-induced alteration of cell surface proteins in 
the heterobasidiomycetous yeast Tremella mesenterica. Journal of Bacteriology 158, 814-819.

Neidhardt, F. C., Van Bogelen, R. A. \& Vaughn, V. (1984). The genetics and regulation of heat-shock proteins. Annual Review of Genetics 18, 295-329.

Paris, S. \& Duran, S. (1985). Cyclic adenosine 3', 5'monophosphate (cAMP) and dimorphism in the pathogenic fungus Paracoccidioides brasiliensis. Mycopathologia 92, 115-120.

Paris, S., Duran-Gonzalez, S. \& Mariat, F. (1985). Nutritional studies on Paracoccidioides brasiliensis: the role of organic sulfur in dimorphism. Sabouraudia 23, 85-92.

Patino, M. M., Burgas, L. C. \& Restrepo, A. (1984). Effect of temperature on the mycelium to yeast transformation of Paracoccidioides brasiliensis. Sabouraudia 22, 509-511.

Restrepo M. A. (1985). The ecology of Paracoccidioides brasiliensis : a puzzle still unsolved. Sabouraudia 23, 323-334.

RESTREPO, A. \& JimenEZ, B. E. (1980). Growth of Paracoccidioides brasiliensis yeast phase in a chemically defined culture medium. Journal of Clinical Microbiology. 12, 279-281.

Restrepo, A., Salazar, M. E., Cano, L. E., Stover, E. P., Feldman, D. \& Stevens, D. A. (1984). Estrogens inhibit mycelium-to-yeast transformation in the fungus Paracoccidioides brasiliensis: implications for resistance of females to paracoccidioidomycosis. Infection and Immunity 46, 346-353.
RIEHL, R. M. \& TofT, D. O. (1984). Analysis of the steroid receptor of Achlya ambisexualis. Journal of Biological Chemistry 259, 15324-15330.

Riehl, R. M., Toft, D. O., Meyer, M. D., Carlson, G. L. \& McMorRIS, T. C. (1984). Detection of a pheromone-binding protein in the aquatic fungus Achlya ambisexualis. Experimental Cell Research 153, 544-549.

Salazar, M. E. \& Restrepo, A. (1984). Morphogenesis of the mycelium to yeast transformation in Paracoccidioides brasiliensis. Sabouraudia 22, 7-11.

San-Blas, F. \& San-Blas, G. (1985). Paracoccidioides brasiliensis. In Fungal Dimorphism with Emphasis on Fungi Pathogenic for Humans, pp. 93-120. Edited by P. J. Szaniszlo \& J. L. Harris. New York: Plenum Press.

SAN-Blas, G. \& Vernet, D. (1977). Induction of the synthesis of cell wall $\alpha 1,3$-glucan in the yeastlike form of Paracoccidioides brasiliensis strain IVIC Pb9 by fetal calf serum. Infection and Immunity 15, 897 902.

Stover, E. P., Schar, G., Clemons, K. V., Stevens, D. A. \& FeldMAN, D. (1986). Estradiol-binding proteins from mycelial and yeast-form cultures of Paracocidioides brasiliensis. Infection and Immunity 51, 199-203.

Yамамото, K. R. (1985). Steroid receptor regulated transcription of specific genes and gene networks. Annual Review of Genetics 19, 209-252. 